\title{
ECOLOGICAL MODELING OF LOCUSTA MIGRATORIA L. BREEDING CONDITIONS IN SOUTH-EASTERN KAZAKHSTAN ${ }^{1}$
}

\section{V. Malakhov}

National Center for Space Research and Technology, Almaty, 050010, Republic of Kazakhstan

E-mail: d_malakhov_73@mail.ru

\section{N. Yu. Tsychuyeva}

National Center for Space Research and Technology, Almaty, 050010, Republic of Kazakhstan E-mail: d_malakhov_73@mail.ru

\section{E. Kambulin}

Zhyembayev's Institute of Plant Protection and Quarantine, Almaty, 040920, Republic of Kazakhstan E-mail: d_malakhov_73@mail.ru

\section{ЭКОЛОГИЧЕСКОЕ МОАЕЛИРОВАНИЕ УСЛОВИЙ РАЗМНОЖЕНИЯ ПЕРЕЛЕТНОЙ САРАНЧИ (LOCUSTA MIGRATORIA L.) В ЮГО-ВОСТОЧНОМ КАЗАХСТАНЕ ${ }^{1}$}

\section{А. В. Малахов \\ Национальный центр космических исследований и технологий, Алма-Ата, 050010, Казахстан E-mail:d_malakhov_73@mail.ru}

\section{Н. Ю. Цычуева}

Национальный иентр космических исследований и технологий, Алма-Ата, 050010, Казахстан E-mail:d_malakhov_73@mail.ru

\section{В. Е. Камбулин}

Институт защиты и карантина растений им. Ж. Жиембаева, Алма-Ата, 040920, Казахстан E-mail: d_malakhov_73@mail.ru

\begin{abstract}
Background. The method of ecological niche modeling (ENM) was applied to reconstruct the nesting conditions of one of the most widely-known pest species, Locusta migratoria asiatica, with a focus of nesting in Balkhash-Alakol basin. The ENM uses a set of input environmental variables to analyze and select the key factors from the entire input set. The key factors are the climatic variables which define the wellbeing of an organism; and the range of these variables may be calculated with statistical and GIS approaches. Materials and methods. The method of ENM used in current paper is referred to as "presence-only" since it utilizes the known localities of the animal (in our study, egg-clutches) to develop a model. The model outlines the area where the successful development of locust egg-boxes is most probable, rather than the actual nesting area. Further analysis of the identified key variables allows definition of the most vulnerable stages of the locust life-cycle. Results. The most important factors, influencing the development of the locust over its life-cycle, are: the ambient air temperature; the temperature of the soil during the cold season of the year; and soil moisture. The locust is an ectotherm organism, which has a restricted ability to regulate its body temperature; and the ambient temperature thus serves as a major factor affecting the animal's behavior. Wintering egg-boxes are immobile and face even more environmental challenges than nymphs or adults do. The soil temperature may not depend upon a single variable, like the air temperature, but is a function of the complex relationship between the thermal properties of the air and soil. The process of the energy flux between soil and atmosphere incudes many factors, particularly related to soilmoisture content and the physical properties of the soil.
\end{abstract}

This work is part of the Republican budget program 076, entitled "Applied scientific research in the field of space activities, transport and communications", under the auspices of the Ministry of Investment and Development of the Republic of Kazakhstan for 2016-2018. 
The analysis of key variables should not be performed without an understanding of the complex relationships between the abiotic components of the environment. Conclusions. Comparative analysis of published data on locust adult and embryo physiology and key-variables, revealed by the model, confirmed the usefulness of the ENM approach for the study of the ecological peculiarities of a living species. Further development of this model with additional variables, gathered with remote sensing, should result in a probabilistic forecasting model aimed to withstand the locust outbreaks.

Key words: Asiatic locust, breeding sites, ecological niche model.

For citation: Malakhov D.V., Tsychuyeva N.Yu., Kambulin V.E. Ecological modeling of Locusta migratoria L. breeding conditions in South-Eastern Kazakhstan. Russian Journal of Ecosystem Ecology. 2018;3(1). Available from: https://doi.org/10.21685/2500-0578-2018-1-5

Аннотация. Общие положения. Метод моделирования экологической ниши (МЭН) применялся для воссоздания условий гнездования одного из наиболее широко известных видов вредителей, а именно перелетной азиатской саранчи Locusta migratoria asiatica, особое внимание уделялось ареалу гнездования в БалхашАлакольском бассейне. Метод МЭН основан на использовании вводных экологических переменных для анализа и выбора ключевых факторов из всей совокупности значений входных данных. Ключевыми факторами являются климатические переменные, определяющие состояние организмаю Расчет диапазона этих переменных может производиться исходя из статистических подходов и подходов, базирующихся на системе обработки географической информации. Материалы и методы. В настоящей статье метод МЭН обозначается только в качестве фактического, поскольку для разработки модели используются известные места обитания животных (в данном исследовании, кладки яиц). Модель описывает область, где кладки яиц саранчи развиваются успешно с наибольшей вероятностью, а не фактическую площадь гнездования. Дальнейший анализ идентифицированных ключевых переменных позволяет определить наиболее уязвимые стадии жизненного цикла саранчи. Результаты. Важнейшими факторами, влияющими на развитие саранчи в течение ее жизненного цикла, являются: температура окружающего воздуха; температура почвы в холодное время года; и влажность почвы. Саранча - это холоднокровный организм, который обладает ограниченной способностью к регуляции температуры тела, тем самым температура окружающей среды является основным фактором, влияющим на поведение животного. Зимующие кладки яиц являются неподвижными, в связи с чем они сталкиваются с большим количеством природных факторов, чем личинки или взрослые особи. Температура почвы не может зависеть от одной переменной, например, температуры воздуха, она определяется на основе сложной взаимосвязи между термическими параметрами воздуха и почвы. Процесс обмена энергией между почвой и атмосферой определяется множеством факторов, особенно связанных с содержанием влаги в почве и физическими свойствами почвы. Для анализа ключевых переменных необходимо понимание сложной взаимосвязи между абиотическими компонентами среды. Выводы. Сравнительный анализ опубликованных данных о физиологии саранчи, физиологии зародышей и ключевых переменных, выявленных на основе применения модели, подтвердил полезность подхода МЭН для изучения экологических особенностей биологических видов. Результатом дальнейшей разработки модели с дополнительными переменными, собранными с помощью дистанционного зондирования, должна стать модель вероятностного прогнозирования, направленная на предотвращение нашествий саранчи.

Ключевые слова: Азиатская саранча, места размножения, модель экологической ниши.

From ancient times, the locust has been well known as an agricultural pest. Locust outbreaks are first mentioned in the Urra-Hubullu (about 2000 $\mathrm{BC}$ ), where they are referred to by the Akkadian word "senu" or "sennu" which means "evil". A locust outbreak was called the "eighth plague of Egypt" in the Bible: "They covered the face of the whole land, so that the land was darkened, and they ate every plant of the land and all the fruit of the trees that the hail had left. Not a green thing remained, neither tree nor plant of the field, through all the land of Egypt." (Ex. 10:5). Repeated locust outbreaks are known from all but the Antarctica continents. An extremely devastating locust outbreak happened, for example, in Mesoamerica (1454 A.D.), when, after a drought, massive invasions of locusts happened. "Place names showed the importance of the insect to Mesoamerican cultures, such as the Nahuatl place name Chapultepec, which translates as "locust hill" [1].

The Asiatic Locust (Locusta migratoria) has the widest area of distribution among all locust species. The area of L. migratoria covers Europe; Africa (including Madagascar); the Arabian and Indian peninsulas; the Caucasus; Central and South-Eastern Asia; Australia; New Zealand; and Papua New Guinea. The northern border of the area of L. migratoria runs along the southern edge of the evergreen forests of Europe and Asia. The species obviously has a wide range of adaptations, allowing it to exist in very diverse ecological and climatic conditions [2]. 
Locust outbreaks have been documented in at least 84 years of the last two centuries (19th20th) within the territory of the former USSR [3]. Kazakhstan is traditionally known as a territory which is frequently affected with locust outbreaks which cause serious damage to crops. For example, the outbreak of 1999 caused damage to at least 200000 ha of agricultural lands; and the subsequent damage was estimated at $\$ 15$ million [4].

Wide feeding adaptations, behavior and migration abilities make the gregarious species of the family Acrididae probably the most prominent pests on the planet [5]. The high propensity for migration of the gregarious species is illustrated by recurrent reports of swarms moving downwind 100 $\mathrm{km}$ or more in a few hours of daytime [6]. On the other hand, the locust is an important part of natural ecosystems that, normally, provide the stability of steppes [7]. The locust in natural conditions consumes only a small portion of the plant, leaving enough vegetation for feeding of other animals. A moderate number of locusts even stimulate vegetation growth. In turn, the locust represents a perfect food resource for very different animals, from invertebrates to mammals.

The locust is characterized by focal nesting behavior and extremely pronounced migration activity. Feeding preferences, larvae and imago behavior, and focal reproduction all together ensure the survival of the species. In the Central Asian region, there are many transboundary breeding areas, which allows for the possibility of a coordinated, preventive approach to combatting outbreaks. Most importantly, the Central-Asian breeding areas of L. migratoria are located in Kazakhstan [8]. L. migratoria nesting areas are associated exceptionally with reeds [9]. The most important breeding areas of L. migratoria are associated with the deltaic and shoreline landscapes of the Aral-Caspian-Pontus depression. Permanent breeding areas of L. migratoria are located in the reed thickets of Kazakhstan in the lower portion of the Zhaik River; around the Kamys-Samara Lakes; along most of the large rivers (Irgiz, Turgay, Syrdarya, Ili, Shu Rivers); and on the banks of the Balkhash and Alakol Lakes, etc. [2]. The exact borders of the nesting foci are uncertain due to significant changes in the natural ecosystems in the last few decades. We attempted to analyze important abiotic variables delimiting the conditions and consequently the area of L. migratoria nesting foci in South-Eastern Kazakhstan, using the rapidly developing Ecological Niche Modeling approach.

Ecological niche modeling (ENM) is the wellanalysed and promising subject of a number of recent scientific studies [10-12]. The modeling itself consists in the determination of the biotic and abiotic variables depicting the species life cycle and spatial distribution according to one or the other approach. Joseph Grinnell appears to have introduced this idea of an ecological niche in 1914 [13]. The concept of an ecological niche, in general terms, is a complex of environmental variables, delimiting the species' existence. The term "ecological niche" usually encompasses the relationships of species, functioning within the common food chain. Having its own niche in the biogeocenosis, the species competes with other species of the given natural community for food, space and other factors which sustain life. In this paper, we accept the concept of an ecological niche formulated by George Hutchinson [14], who further formalized the niche concept as an attribute of the species, not the environment. The niche was described in a space (n-dimensional hypercube) of environmental variables, biotic and abiotic, some of which outline the limits of species viability [14]. It is possible to distinguish: 1) a spatial niche concerned with the peculiarities of species distribution; 2) a functional (trophic) niche linked to food sources; metabolic and growth ratio; and the co-influence of a given species on others, etc.; 3) a multidimensional niche in $\mathrm{n}$-dimensional hyperspace, where $\mathrm{n}$ represents the number of all variables and relationships, allowing successful species reproduction. All niche types can be described and estimated quantitatively, though with varying degrees of accuracy [14].

GIS-based ENM is a rapidly developing area of research that has many different approaches and perspectives [15]. Recently, the GIS-based ENM approach was applied to very different groups of living organisms. Aguilar and Lado [16] developed an ENM for protists. Studies have been recently published devoted to ENM of different fungal [17] and plant species [18]; insects [19-21]; reptiles [22-25]; birds [26-28]; mammals [29, 30]; and even cryptozoological objects [31]. This approach appears a good and reliable tool for past and future climatic scenario studies [32, 33]. However, we are not aware of any recent paper relating to the ecological niche of L. migratoria; and our current experience therefore may be seen as an initial step to the extended study of L. migratoria ecology employing statistical and geospatial approaches.

\section{Material and methods}

The research area, corresponding to the Balkhash or Balkhash-Alakol breeding focus, is located in the River Ili delta, close to the southern border of Lake Balkhash. It is estimated that the breeding area occupies as much as $37400 \mathrm{~km}^{2}$. Figure 1 represents the location of the study area. 
The greater part of the region consists of gradually sloping alluvial lacustrine plains with hilly aeolian sands. Saryesik-Atyrau and Moinkum Sands are the largest sandy areas in the region. Reeds and cattails grow in the river floodplain, along with riparian tugai forests, typical of the desert rivers of Central Asia. The Tugai forests consist of thickets of trees and shrubs (such as Pópulus euphrática, different willow species, Tamarix and Halimodendron, etc.), entwined with vines (such as Clematis and Calistegiya). Reed grass, wheatgrass and a few other species make up the rather sparse grasscover in the area.

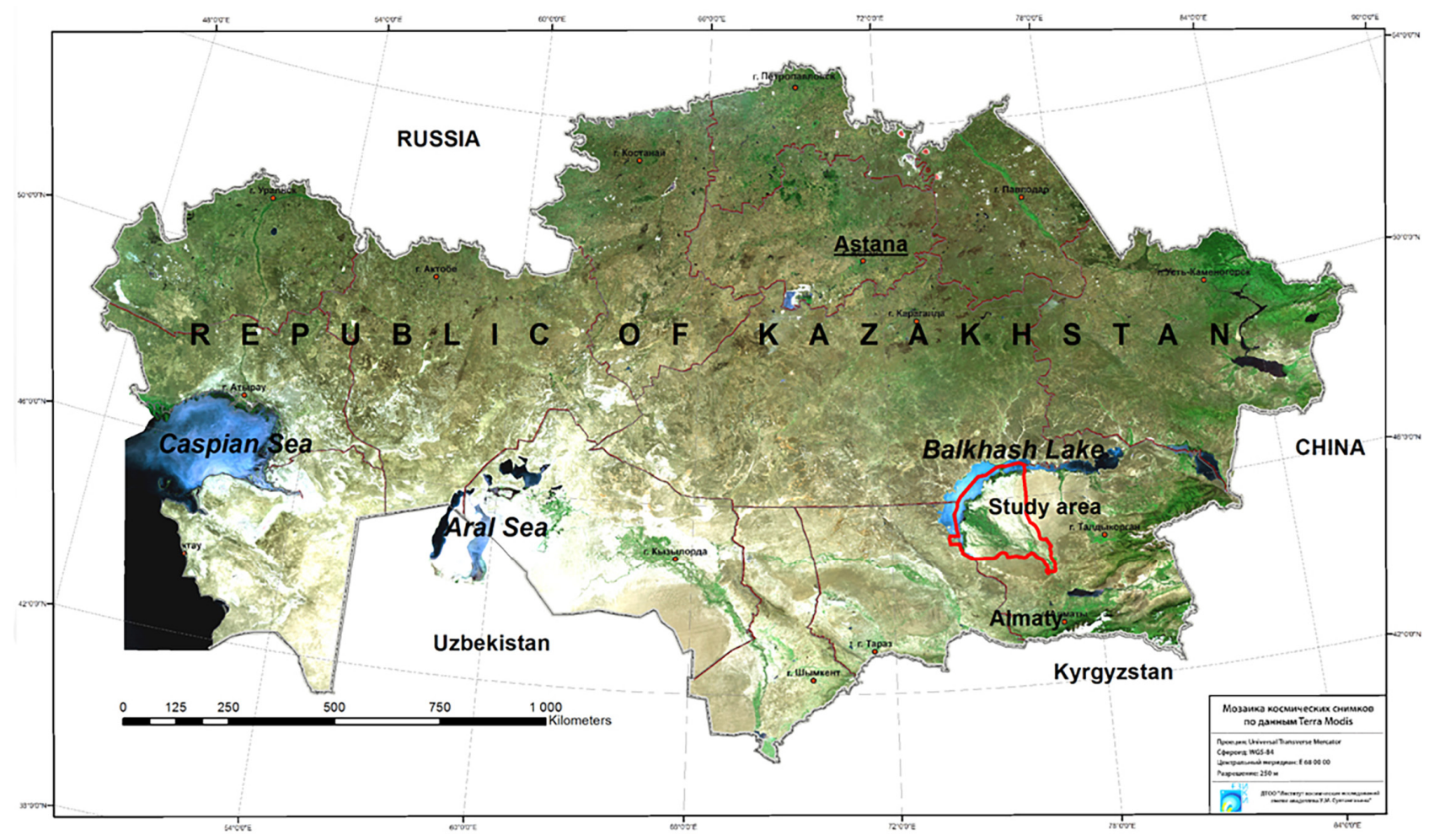

Fig. 1. Study area depicted with red polygon

The territory of the Balkhash-Alakol breeding area is a structural part of an intermountain depression, located between Tarbagatay Ridge at the north, the Shu-Ili Mountains to the west and the Jungar Alatau spurs at the south and southeast. In terms of climate, the area is a temperately warm, arid zone with a continental climate, harsh winters, low annual precipitation (about $100 \mathrm{~mm}$ ) and dry, hot summers [34].

A series of field surveys had been conducted within the study area for several years $(2010,2011$, 2015,2016 ), collecting data on egg-boxes and early nymph locations. We used 69 field points to elaborate a model of the nesting conditions of L. migratoria. $75 \%$ (51 points) of all the points were used to define the basic variable ranges; and the remaining $25 \%$ ( 18 points) served to define the key variables as described in detail by Malakhov et al. [17], and Dujsebayeva, Malakhov [35]. Climatic datasets were then employed to develop the model. These were: WorldClim (monthly temperatures and precipitation); BioClim (a set of variables derived from WorldClim and meteorological stations http://www.worldclim.org/); Global Poten- tial Evapo-Transpiration (http://www.cgiarcsi.org/data/global-aridity-and-pet-database); and the Digital Elevation Model and its derivatives (exposition, slope, curvature etc.). Input of data and model development were performed in the ESRI ArcGIS 10.1 environment. A detailed description of the climatic variables is available online and has been published in a number of papers $[20,36,37,38,39]$. Statistical analysis of data was carried out using STATSOFT Statistica 12.

\section{Results}

The results of the nesting conditions of $L . m i-$ gratoria in South-Eastern Kazakhstan are represented as a list of key environmental variables, revealed with control points and a map of spatial distribution of optimal nesting conditions for the species.

Table 1 contains the key abiotic variables, as identified by statistical analysis, describing the nesting conditions of L. migratoria in Balkhash Alakol. 
A review of the table shows the prevalence of cold-season variables. Egg-wintering is most important and vulnerable stage in the species' annual cycle. Mobile insects have evolved some adaptations or regulating mechanisms to avoid extreme warming and the lack of food in spring and summer. Wintering eggs, by contrast, will survive or die during the cold season, having no opportunity of avoiding extra-cooling or excessive soil moisture. A few variables (annual precipitation and precipitation in the driest quarter) are not directly related to egg wintering and, most probably, are re- related to the condition of the vegetation, which in turn may regulate the transition from the solitary to the gregarious phase. The influence of precipitation in March and October is questionable, since we cannot define the direct impact of those variables on the locust. It is possible to hypothesize the existence of a certain optimal range for these variables, regulating either the soil conditions (temperature, moisture, energy balance) or the water content in the soil, and in turn regulating the viability of egg-boxes.

Table 1

The list of key variables for Locusta migratoria breeding conditions

\begin{tabular}{|c|c|}
\hline Variable & Optimal interval \\
\hline February min temperature, ${ }^{\circ} \mathrm{C}$ & $-15,2 \ldots-13,6$ \\
\hline March min temperature, ${ }^{\circ} \mathrm{C}$ & $-6,4 \ldots-5,3$ \\
\hline April min temperature, ${ }^{\circ} \mathrm{C}$ & $4,1 \ldots 4,6$ \\
\hline December min temperature, ${ }^{\circ} \mathrm{C}$ & $-11,4 \ldots-10,2$ \\
\hline February mean temperature, ${ }^{\circ} \mathrm{C}$ & $-10,1 \ldots-8,7$ \\
\hline March mean temperature, ${ }^{\circ} \mathrm{C}$ & $-1,9 \ldots-0,6$ \\
\hline April mean temperature, ${ }^{\circ} \mathrm{C}$ & $9,5 \ldots 10,1$ \\
\hline December mean temperature, ${ }^{\circ} \mathrm{C}$ & $-7,2 \ldots-6$ \\
\hline February max temperature, ${ }^{\circ} \mathrm{C}$ & $-5,2 \ldots-3,7$ \\
\hline November max temperature, ${ }^{\circ} \mathrm{C}$ & $3,8 \ldots 4,8$ \\
\hline December max temperature, ${ }^{\circ} \mathrm{C}$ & $-2,9 \ldots-1,7$ \\
\hline March precipitation, $\mathrm{mm}$ & $14 \ldots 19$ \\
\hline October precipitation, $\mathrm{mm}$ & $15 \ldots 21$ \\
\hline January PM relative humidity, $\%$ & $60,96 \ldots 62,78$ \\
\hline February PM relative humidity, $\%$ & $59,9 \ldots 60,9$ \\
\hline March PM relative humidity, $\%$ & $57,0 \ldots 58,8$ \\
\hline June PM relative humidity, $\%$ & $35,3 \ldots 36,4$ \\
\hline October PM relative humidity, $\%$ & $46,3 \ldots 47,5$ \\
\hline November PM relative humidity, $\%$ & $56,45 \ldots 57,9$ \\
\hline February AM relative humidity, $\%$ & $91,58 \ldots 93,84$ \\
\hline April AM relative humidity, $\%$ & $60,5 \ldots 61,1$ \\
\hline November AM relative humidity, $\%$ & $80,4 \ldots 81,7$ \\
\hline April solar radiation & $165,3 \ldots 168,5$ \\
\hline Bio12, Annual Precipitation, $\mathrm{mm}$ & $142,8 \ldots 192,4$ \\
\hline Bio17, Precipitation of driest quarter, $\mathrm{mm}$ & $18,23 \ldots 28,1$ \\
\hline Bio19, Precipitation of coldest quarter & $36,9 \ldots 45,1$ \\
\hline Bio21, Highest weekly radiation $\left(\mathrm{W} / \mathrm{m}^{2}\right)$ & $242,8 \ldots 248,4$ \\
\hline Aridity Index & $1540 \ldots 2094$ \\
\hline
\end{tabular}

* - see [40] on relative humidity calculation details;

** - see [41] on Aridity Index details.

Figure 2 represents the basic model of $L$. migratoria nesting conditions in South-Eastern Kazakhstan.

The map is a result of summarizing the key variables (Table 1). The basic model, considering only abiotic variables, reveals a much wider range of suitable nesting areas for L. migratoria than is known from previously published data. Shaded polygons on the map depict the area of nesting foci of L. migratoria as known in the mid 20th century
[42]. However (see Discussion), one of the most important factors, defining the successful reproduction of the species in nature, is the presence of reeds, needed for locust feeding. The addition of recent distribution areas of reeds (black polygons) to the basic model significantly reduces the area of nesting foci. The question of the actual distribution of L. migratoria nesting sites is still debatable and requires more detailed study, since the current environmental situation differs from the situation fif- 
ty years ago, particularly with the distribution of reeds.

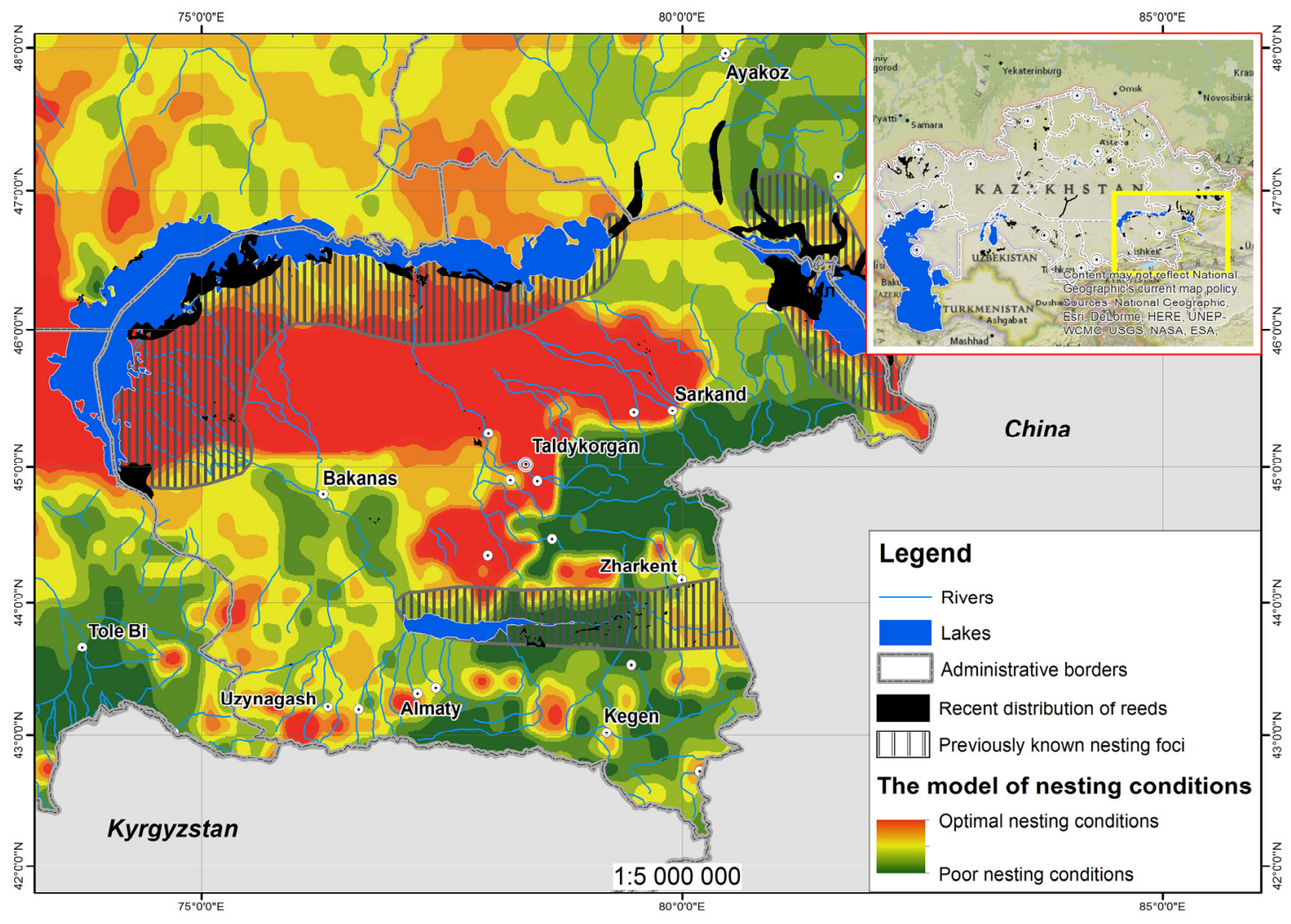

Fig. 2. The ecological model of L. migratoria nesting conditions

\section{Discussion}

\section{Air and soil temperature}

The model reflects the impact of environmental variables crucial to the well-being of the locust. Any species exists within a system of "atmosphere-plants-animals-soil": a complicated equilibrium with many interacting factors like temperature, wetness, soils, etc. Within continental arid climate, some of the factors, having their highest values in particular seasons, may provide additional constraints to biota. For locusts, the main factors are extremely high summer temperatures and extremely low winter temperatures. In particular, winter temperatures may cause the freezing of the uppermost soil layers and this appears to be fatal for wintering eggs. The energy balance within the soil is a key parameter for the survival of eggboxes.

M. Petrov [43] distinguishes two main stages of energy balance for Middle Asian deserts: the soilwarming stage (January-July); and the soil-cooling stage (August-December). Rainfall provides surface moisture that has a warming effect on the surface and subsurface soil layers, especially in sandy soils, during the cool season of the year. This phenomenon is related to changes in the thermal conductivity of wet and dry soil. Dry soil has less con- ductivity and so may not conduct energy from the sub-surface levels to the surface as successfully as wet soil does. Wet soil makes the movement of heat from the depth to the surface more intensive and obvious. We can hypothesize that the levels of precipitation in March and October, which emerge as key variables in our model, have a smoothing effect on soil-temperature balance during the most unstable seasons.

For ectotherm species, such as insects, temperature has long been recognized as a major environmental factor responsible for species abundance and geographic distribution. The capacity to adapt to and tolerate extreme temperature is thus critical for the persistence of ectotherm populations. When exposed to extreme temperatures, insects may respond in different ways: they may behaviorally avoid extremes by escaping the adverse conditions; or respond through changes in morphology, life history and/or physiology [44].

Thermal peculiarities have a diverse and complex influence on mobile insects and egg-boxes. Adult locusts are quite flexible in avoiding temperature extremes; but some constraints still exist. In contrast to other insect species which have evolved behavioral and physiological mechanisms for thermoregulation during flight, locusts are not known to regulate their thoracic temperature during flight [45]. In turn, the locust's flight ability is 
itself temperature-dependent. The thoracic temperature of a flying locust generally exceeds the ambient temperature by $5-8{ }^{\circ} \mathrm{C}$. The minimum thoracic temperature to initiate flight is $24^{\circ} \mathrm{C}$; and the maximum temperature for flight-muscle contraction is $42{ }^{\circ} \mathrm{C}$ [45]. It was shown [46], that adult locusts have limited ability to withstand air temperatures higher than the lethal internal temperature $\left(48{ }^{\circ} \mathrm{C}\right)$ for more than an hour, during which time they maintain an internal temperature as much as $8{ }^{\circ} \mathrm{C}$ below air temperature.

The feeding process of nymphs and adults also demonstrates this temperature dependence. The body mass of a single locust increases as much as 45 times (from 0.02 to $0.95 \mathrm{~g}$ ) from hatchling to early-adult age [47]. Experiments on the growth of locusts in different temperature conditions [48] revealed that the optimal range is about $32{ }^{\circ} \mathrm{C}$, when dry mass gain, protein and carbohydrates utilization efficiency were greater compared with higher $\left(38^{\circ} \mathrm{C}\right)$ and lower $\left(26^{\circ} \mathrm{C}\right)$ temperatures. The adult stage is also harmed by low temperature: at $18{ }^{\circ} \mathrm{C}$ no mating occurred; at $21{ }^{\circ} \mathrm{C}$ and below females were unable to lay eggs; and at $24^{\circ} \mathrm{C}$ adult females laid their first egg pod significantly later than at $30{ }^{\circ} \mathrm{C}$ [49]. The lower temperature threshold of L. migratoria nymphs has been defined as $16-17{ }^{\circ} \mathrm{C}$ [9]. Hatching may take place when the soil temperature is between $20-40{ }^{\circ} \mathrm{C}$. Nymphs feed when the body temperature is between 25 and $30^{\circ} \mathrm{C}$. The feeding temperature threshold is $19-38{ }^{\circ} \mathrm{C}$. If nymphs experienced lack of water or food, they may feed in the night when the air temperature decreases to $15-16{ }^{\circ} \mathrm{C}$. Eggs in diapause have an optimum temperature of $0-4{ }^{\circ} \mathrm{C}$. Eggs become unviable when the temperature is below $-17^{\circ} \mathrm{C}$ and above $60{ }^{\circ} \mathrm{C}$.

Wintering eggs represent the most vulnerable stage of the locust's annual cycle. Experiments on eggs supercooling [50] identified the supercooling point as minus $20^{\circ} \mathrm{C}$. However, most eggs died at temperatures above this point, indicating the occurrence of pre-freezing mortality. Table 2 demonstrates a summary of $L$. migratoria thermal requirements.

Table 2

Thermal requirements of Locusta migratoria

\begin{tabular}{|c|c|c|c|c|c|}
\hline \multicolumn{2}{|c|}{ Adult body temperature, ${ }^{\circ} \mathbf{C}$} & \multicolumn{3}{c|}{ Egg incubation temperature, ${ }^{\circ} \mathbf{C}$} \\
\hline Lower limit & Optimum & Upper limit & Lower limit & Optimum & Upper limit \\
\hline 15 & $19 \ldots 38$ & 48 & -21 & $0 \ldots 4$ & 60 \\
18 (lower & $\begin{array}{c}24 \ldots 42 \\
\text { mating limit) }\end{array}$ & & & & \\
\hline
\end{tabular}

The current model allows limited but effective explanations of key-variable impact and variable importance for the locust during the separate stages of the entire annual cycle. It is possible to estimate the soil temperature using measurements of air temperature and to estimate the egg-boxes' wintering-temperature conditions. For bare soils, surface temperature is primarily a function of surface-soil moisture [51, 52]. A strong positive correlation be- tween air temperature (variables, used in current model) and soil temperature was repeatedly demonstrated in several studies [53-55]. Using methods developed by Ahmad and Rasul [53] and Islam et al. [54], it is possible to measure indirectly the soil temperature as a function of air temperature at the depth of $10 \mathrm{~cm}$ for key temperature variables, revealed by the model (Table 3 ).

Estimation of soil temperature by minimal and mean air temperatures.

Extreme values of an estimated soil temperature are given in bold

\begin{tabular}{|l|c|c|c|}
\hline \multicolumn{1}{|c|}{ Variable } & Range & $\begin{array}{c}10 \mathrm{~cm} \text { soil } \\
\text { temperature by }[53]\end{array}$ & $\begin{array}{c}10 \mathrm{~cm} \text { soil } \\
\text { temperature by }[54]\end{array}$ \\
\hline December minimal temperature & $-11,4 \ldots-10,2$ & $-3,1 \ldots-2,3$ & $-3,37 \ldots-2,36$ \\
\hline February minimal temperature & $-15,2 \ldots-13,6$ & $-5,99 \ldots-4,86$ & $\mathbf{- 6 , 5 7 \ldots - 5 , 2 2}$ \\
\hline March minimal temperature & $-6,4 \ldots-5,3$ & $-6,4 \ldots-5,1$ & $0,82 \ldots 1,76$ \\
\hline April minimal temperature & $4,1 \ldots 4,6$ & $5,7 \ldots 6,3$ & $9,6 \ldots 10,1$ \\
\hline February mean temperature & $-10,1 \ldots-8,7$ & $-2,23 \ldots-1,2$ & $-2,8 \ldots-1,1$ \\
\hline March mean temperature & $-1,9 \ldots-0,6$ & $-1,29 \ldots 0,29$ & $4,62 \ldots 5,71$ \\
\hline April mean temperature & $9,5 \ldots 10,1$ & $11,9 \ldots 12,7$ & $\mathbf{1 4 , 2 \ldots 1 4 , 7}$ \\
\hline
\end{tabular}


A soil depth of $10 \mathrm{~cm}$ is enough to house an L. migratoria egg-box 5-8 cm long [56].

Comparison of the data from tables 2 and 3 demonstrates the relative concordance of the physiological requirements for egg incubation and the range of temperature variables, as provided by the model. Soil temperature estimated roughly does not exceed the lower and upper thresholds of incubation temperatures as allocated close to the optimal range, even in the coldest months. Soiltemperature estimation is quite accurate for our study, as we deal with approximated temperature values from climatic datasets. Further implementation of the variable values might be focused at the adult locust body-temperature estimation. There is no direct approach to estimate the locust body temperature; but the close relation of locust body and soil temperatures should be assumed, as it was demonstrated for an ectotherm vertebrate (Varanus griseus) [57]. Such relation being well-documented would allow the locust body temperature to be estimated at a known air temperature, which in turn is bound to the soil temperature. This question requires further experimental work to be undertaken. The analysis of modeling the key variables confirms the importance of a cold season for the survival of the species. If low temperature is a fundamental factor of population growth, global climatewarming may be partially responsible for locust movement northward [50].

\section{Precipitation and soil moisture}

Along with the thermal conductivity of the soil, precipitation may affect the soil-moisture conditions for egg wintering and incubation. Furthermore, the correlation of above-mentioned temperatures to soil moisture was studied for different climatic conditions and soil depths and found to be strong as well [51, 52]. However, we expect more complicated relationships between soil moisture, air condition and ambient air temperature. It is difficult to explain the importance of one variable without taking into account its complex interaction with other variables. Air condition is related to soil-moisture level in a complex way [58]. Soil respiration is influenced by temperature and soil moisture [59]. Relative humidity at the soil surface, as a function of soil moisture, determines the division of surface energy into sensible and latent heat. Soil heat flux is influenced by wetness, since thermal conductivity is closely related to moisture potential [60]. The decreasing precipitation followed by temperature increase may be related to locust outbreaks [61]. B. P. Uvarov [62] proposed an elegant explanation of drought and its relationship to subsequent locust outbreaks. "Open semi- desert and desert beyond the plains are characterized by extreme diurnal fluctuations of temperature and low air-humidity especially during the summer months when the locusts are approaching sexual maturation, the success of which depends on humidity. The conditions inside the dense continuous stands of tall reeds are entirely different, as the lack of ventilation and the presence of water or of wet soil combine to create a hothouse atmosphere (somewhat resembling sub-tropical areas). Marginal zones of such reeds and sandy "islands" offer the most favorable conditions for egg-laying. A series of years with low flood levels favors the expansion of the more xerophilous vegetation types, i.e. the locust oviposition habitat. The food/shelter habitat of reeds may be reduced in such years, although it never can become insufficient for the needs of locust, and the total result is an increase in locust population and its concentration in smaller areas" [62]. Additionally, he emphasized the deadly impact of high floods on locust egg-boxes [62]; and this circumstance may explain the importance of the October and March precipitation in our model, as excessive rainfalls at these times may cause the flooding of depressed areas and lowlands. The Aridity Index, revealed as one of key variables by the model, indicates the habitat of $L$. migratoria breeding focus in the South-Eastern area as "Arid" [41], where drought events are an ordinary occurrence. The analysis of a thousand-year period in China confirmed the importance of floods and droughts as regulators of locust abundance in the Lower Yangtze River [63].

\section{Other variables}

Apart from abiotic variables, the main factor delimiting the nesting location is the presence of the green biomass needed for adult feeding and sexual maturation. Grasscover is also an important factor, as egg-lays are denser when the grasscover is considerably sparse [2, 62]. Vegetation debris, an obstacle for egg laying, should not be scattered across the entire soil surface. Major places for locust egg-lays in the Ili River delta are southern hill slopes and dried lakes and channel bottoms which have banks covered with reeds. At 28 out of the 37 sites (76 \%) where nymphs were present in 2007 , reeds were the dominant vegetation. Bare ground was the major land type at the nine remaining sites [64].

In general, plant communities with reeds predominating occupy at least $20 \%$ of the overall vegetated area in the Ile River Delta [65]. To improve the basic model with an important variable, "distribution of reeds", we used satellite imagery (TERRA/MODIS) and specialized software (Exelis ENVI 5.2) for the identification of reeds. The area 
of reeds was obtained from satellite imagery for May 2016 in line with previously published methods of the parametric classification of vegetation cover in arid areas [66, 67]. A field survey in 2016 revealed a good coincidence of the modeled conditions to the actual distribution of egg-boxes and young nymph locations. $88 \%$ of documented eggboxes and young nymphs fall within the "good" and "perfect" ranges of the basic model; and $72 \%$ of documented egg-boxes and young nymphs were found within the distance of 1 kilometer or less from reeds, as derived from satellite imagery.

\section{Conclusion}

The basic model demonstrates good spatial agreement with the published data on L. migratoria nesting foci distribution [42], though some areas require further study. The recent status of the Balkhash nesting focus confirms the decrease in areas suitable for nesting comparing to the previously published data of the early [68] and late twentieth century [42]. This general trend of suitable nesting areas decrease persisted throughout the entire twentieth century and relates to ongoing aridification resulting in particular in the shrinkage of areas of reeds.

Another purpose of the current study is to elaborate a probabilistic model for the nesting conditions of L. migratoria. Ideally, this model should serve as a tool for outbreak forecasting. A locust outbreak is a mostly physiological phenomenon, regulated by biotic and abiotic environmental variables [69]. An outbreak resulting in food shortage in the nesting area leads to the transformation of the solitary phase into the gregarious one and, further, to mass migration of the gregarious adults. In evolutionary terms, migration is an adaptation to adverse circumstances and allows the insects to keep pace with changes in habitats, especially in temporary habitats. It serves as an alternative to diapause for tracking resources in space. The ecological significance of migration is to enable insects to spend different parts of their life in different environments. Locust migration is stimulated by ecological events during overcrowding of the locust population. Typically [70], as much as $97-98 \%$ of locust juveniles would not be able to survive past the imago stage. However, in the event of an outbreak, the number of young nymphs increases dramatically, preserving the population density at a high level. When the density increases, the morphology, physiology, and behavior of individuals switch in a very short time (two hours) to the gregarious phenotype. In this form, individuals no longer show mutual repulsion. They form massive swarms of up to $10^{11}$ species that migrate en masse and land in agricultural areas where they deplete crops with devastating speed [71].

The model itself and the knowledge of the most vulnerable stages of locust development may serve as a base for more effective development of outbreak-prevention measures. In the recent past, the most common way of dealing with locust swarms is the application of pesticides. This approach has two great drawbacks. First, insecticides are harmful for other invertebrates and vertebrates. Second, insecticides usually sprayed over a huge area and this is not a cost-effective approach as at least part of pesticide simply goes to waste. Precise information on egg-box concentration for a given year would allow accurate use of pesticide or the application of new, perspective methods [72-75]. The ideal method of outbreak suppression is a "preventive" approach, based on effective monitoring of locust habitats during the critical periods of its annual cycle in order to achieve early detection of nymphs and changes in locust behavior. This approach provides adequate early warning and effective response aimed at reducing the frequency and intensity of locust outbreaks locally and preventing their progress to a large-scale outbreak. The "preventive" approach assumes the long-term and sustainable management of locust populations; and prevention is a comprehensive strategy that takes into account all the situations and all aspects, including preparedness plans and contingency.

\section{Acknowledgements}

We commend Mrs. Ainur Aisarova for her assistance in processing field and climatic data. We are grateful to R. Sim for English correction (http://www.expert-english.com/).

\section{Библиографический список}

1. Few, M. Centering Animals in Latin American History / M. Few, Z. Tortorici. - Durham : Duke University Press, 2013. $-391 \mathrm{p}$.

2. Камбулин, В. Е. Азиатская саранча - вчера, сегодня и завтра / В. Е. Камбулин // Инновационные экологически безопасные технологии защиты растений : материалы Междунар. науч. конф. (24-25 сентября 2015 г.). - Алматы, 2015. - С. 36-42.

3. Sergeyev, M. G. Gregarious locusts: the beginning of the coming century / M. G. Sergeyev, A. V. Latchininsky // Entomological Research North Asia. - 2006. - P. 284-286. 
4. Гаппаров, Ф. А. Саранчовая проблема в Центральной Азии / Ф. А. Гаппаров, А. В. Лачининский // Фундаментальные проблемы энтомологии в 21 веке : материалы Междунар. науч. конф. (Санкт-Петербург, 16-20 мая 2011 г.). - СПб, 2011. - С. 30.

5. Latchininsky, A. V. Locusts and us: The 21st century science vs. the Biblical enemy / A. V. Latchininsky // Fundamental problems of Entomology in XXI century : materials of International scientific conference. - SaintPetersburg, 2011. - P. 87.

6. Outbreaks, gene flow and effective population size in the migratory locust, Locusta migratoria: a regional-scale comparative survey / M.-P. Chapuis, A. Loiseau, Y. Michalakis, M. Lecoq, A. Franc, A. Estoup // Molecular Ecology. - 2009. - № 18. - Р. 792-800.

7. Куришбаев, А. К. Превентивный подход в решении проблемы нашествия саранчи в Казахстане и приграничных территориях / А. К. Куришбаев, В. К. Ажбенов // Вестник науки Казахского агротехнического университета им. С. Сейфуллина. - 2013. - № 1 (76). - С. 42.

8. Мальковский, М. П. Некоторые вопросы изменения численности саранчовых в Казахстане в связи с организационно-хозяйственными мероприятиями в сельском хозяйстве / М. П. Мальковский // Тр. НИИ защиты растений Казахской акад. с.-х. наук. - 1961. - № 6. - С. 47-52.

9. Попова, Е. Н. Вредные саранчовые на юге России и климатические факторы, влияющие на их размножение и распространение / Е. Н. Попова, И. О. Попов // Проблемы экологического мониторинга и моделирования экосистем. - 2009. - Т. XXII. - С. 124-146.

10. Franklin, J. Mapping species Distributions. Spatial inference and prediction / J. Franklin. - Austin ; Texas : Cambridge University Press, 2012. - 320 p.

11. Graham, C. H. A comparison of methods for mapping species ranges and species richness / C. H. Graham, R. J. Hijmans // Global Ecology and Biogeography. - 2006. - Vol. 15. - P. 578-587.

12. Raxworthy, C. J. Applications of Ecological Niche Modeling for Species Delimitation: A Review and Empirical Evaluation Using Day Geckos (Phelsuma) from Madagascar / C. J. Raxworthy, C. M. Ingram, N. Rabibisoa, R. G. Pearson // Syst. Biol. - 2007. - Vol. 56, iss. 6. - P. 907-923.

13. Pocheville, A. The ecological niche: History and Recent Controversies / A. Pocheville // Handbook of Evolutionary Thinking in the Sciences. - 2015. - P. 547-586. DOI: 10.1007/978-94-017-9014-7_26.

14. Hutchinson, G. E. Concluding remarks / G. E. Hutchinson // Cold Spring Harbor Symposia on Quantitative Biology. - 1957. - Vol. 22 (2). - P. 415-427. DOI: 10.1101/sqb.1957.022.01.039.

15. Rushton, S. P. New paradigms for modelling species distributions? / S. P. Rushton, S. J. Ormerod, G. Kerby // Journal of Applied Ecology. - 2004. - Vol. 41. - P. 193-200.

16. Aguilar, M. Ecological niche models reveal the importance of climate variability for the biogeography of protosteloid amoebae / M. Aguilar, C. Lado // The ISME Journal. - 2012. - № 6. - P. 1506-1514.

17. Малахов, Д. В. Моделирование экологической ниши септориоза пшеницы с применением данных дистанционного зондирования Земли / Д. В. Малахов, Н. Ю. Цычуева, И. С. Витковская // Современные проблемы дистанционного зондирования Земли из космоса. - 2017. - T. 14 (1). - С. 113-124. DOI: 10.21046/20707401-2017-14-1-113-124.

18. Species distribution models: ecological explanation and prediction of an endemic and endangered plant species (Pterocarpus santalinus L.f.) / Sh. Babar, G. Amarnath, C. S. Reddy, Anke Jentsch, S. Sudhakar // Current Science. - 2012. - Vol. 102, № 8 (25). - P. 1157-1165.

19. Habitat suitability and ecological niche profile of major malaria vectors in Cameroon / D. Ayala, C. Costantini, K. Ose, G. C. Kamdem, C. Antonio-Nkondjio, J.-P. Agbor, P. Awono-Ambene, D. Fontenille, F. Simard // Malaria Journal. - 2009. - № 8. - P. 307.

20. Beaumont, L. J. Predicting species distributions: use of climatic parameters in BIOCLIM and its impact on predictions of species' current and future distributions / L. J. Beaumont, L. Hughes, M. Poulsen // Ecological Modelling. 2005. - № 186. - P. 250-269.

21. Sanchez, I. Ecological Niche Modeling of Seventeen Sandflies Species (Diptera, Psychodidae, Phlebotominae) from Venezuela / I. Sanchez, J. Liria, M. D. Feliciangeli // International Journal of Zoology. - 2009. - Vol. 2015. 9 p. DOI: http://dx.doi.org/10.1155/2015/108306.

22. Groff, L. A. Using Ecological Niche Models To Direct Rare Amphibian Surveys: A Case Study Using The Oregon Spotted Frog (Rana pretiosa) / L. A. Groff, S. B. Marks, M. P. Hayes // Herpetological Conservation and Biology. 2013. - № 9 (2). - P. 354-368.

23. Distribution and conservation status of the far eastern tree frog, Hyla japonica Günther, 1859 In Mongolia And Transbaikalia (Russia) / S. N. Litvinchuk, N. A. Schepina, M. Munkhbaatar, Kh. Munkhbayar, L. J. Borkin, V. I. Kazakov, D. V. Skorinov // Russian Journal of Herpetology. - 2014. - Vol. 21, № 4. - P. 303-314.

24. Malakhov, D. V. High endemism of Ranodon sibiricus (Amphibia: Urodela: Hynobiidae): evidences from GIS and Remote Sensing Data / D. V. Malakhov, T. N. Dujsebayeva // Proceedings of the International Symposium on Biological Resources Protection and Management in the Arid Central Asia. - Urumqi ; Xinjiang, 2014. - P. 6-7.

25. Distribution And Conservation Status Of The Caucasian Newt, Lissotriton lantzi (Wolterstorff, 1914) / D. V. Skorinov, I. V. Doronin, A. A. Kidov, B. S. Tuniyev, S. N. Litvinchuk // Russian Journal of Herpetology. 2014. - Vol. 21, № 4. - P. 251-268. 
26. Relating Habitat and Climatic Niches in Birds / J-Y. Barnagaud, V. Devictor, F. Jiguet, M. Barbet-Massin, I. Le Viol // PLoS ONE. - 2012. - № 7 (3). DOI:10.1371/journal.pone.0032819.

27. Parra, J. L. Evaluating alternative data sets for ecological niche models of birds in the Andes / J. L. Parra, C. C. Graham, J. F. Freile // Ecography. - 2004. - Vol. 27. - P. 350-360.

28. Peterson, A. T. Using Ecological-Niche Modeling to Predict Barred Owl Invasions with Implications for Spotted Owl Conservation / A. T. Peterson, C. R. Robins // Conservation Biology. - 2003. - Vol. 17, № 4. - P. 11611165.

29. Kayijamahe, E. Spatial modelling of mountain gorilla (Gorilla beringei beringei) habitat suitability and human impact / E. Kayijamahe // PhD Thesis, International Institute for Geo-Information Science and Earth Observation. Enschede. -2008 . -50 p.

30. Rood, E. Using presence-only modelling to predict Asian elephant habitat use in a tropical forest landscape: implications for conservation / E. Rood, A. A. Ganie, V. Nijman // Diversity and Distributions. - 2010. - № 16. P. 975-984.

31. Lozier, J. D. Predicting the distribution of Sasquatch in western North America: anything goes with ecological niche modelling / J. D. Lozier, P. Aniello, M. J. Hickerson // Journal of Biogeography. - 2009. - Vol. 36, iss. 9. P. 1623-1627. DOI: 10.1111/j.1365-2699.2009.02152.x.

32. Дуйсебаева, Т. Н. Прогноз динамики ареала редкой горной амфибии в условиях изменения климата / Т. Н. Дуйсебаева, Д. В. Малахов, А. В. Чередниченко // Desertification of Central Asia: Assessment, Forecast, Management : 1st International Scientific and Practical Conference. - Астана, 2014. - С. 206-211.

33. Locating Pleistocene Refugia: Comparing Phylogeographic and Ecological Niche Model Predictions / E. Waltari, R. J. Hijmans, A. T. Peterson, A. S. Nyari, S. L. Perkins, R. P. Guralnick // PLoS ONE. - 2007. - № 2(7). DOI:10.1371/journal.pone.0000563.

34. Плисак, Р. П. Изменение растительности дельты реки Или при зарегулировании стока / Р. П. Плисак // Алма-Ата : Наука, 1981. - 215 с.

35. Dujsebayeva, T. N. The Model of Ranodon sibiricus Ecological Niche: GIS and Remote Sensing Approach / T. N. Dujsebayeva, D. V. Malakhov // Russian Journal of Herpetology. - 2017. - Vol. 24, № 3. - P. 171-192.

36. O'Donnell, M. S. Bioclimatic predictors for supporting ecological applications in the conterminous United States / M. S. O’Donnell, D. A. Ignizio // U.S. Geological Survey Data Series. - 2012. - Vol. 691. - 10 p.

37. Very high resolution interpolated climate surfaces for global land areas / R. J. Hijmans, S. E. Cameron, J. L. Parra, P. G. Jones, A. Jarvis // International Journal of Climatology. - 2005. - Vol. 25. - P. 1965-1978.

38. Booth, T. H. BIOCLIM: the first species distribution modelling package, its early applications and relevance to most current MAXENT studies / T. H. Booth, H. A. Nix, J. R. Busby, Michael F. Hutchinson // Diversity and Distributions. - 2014. - Vol. 20. - P. 1-9.

39. CliMond: global high-resolution historical and future scenario climate surfaces for bioclimatic modelling / D. J. Kriticos, B. L. Webber, A. Leriche, N. Ota, I. Macadam, J. Bathols, J. K. Scott // Methods in Ecology and Evolution. - 2012. - Vol. 3. - P. 53-64. DOI: 10.1111/j.2041-210X.2011.00134.x.

40. New, M. A high-resolution data set of surface climate over global land areas / M. New, D. Lister, M. Hulme, I. Makin // ClimRes. - 2002. - Vol. 21. - P. 1-25.

41. Trabucco, A. Global Potential Evapo-Transpiration (Global-PET) and Global Aridity Index (Global-Aridity) GeoDatabase. CGIAR Consortium for Spatial Information / A. Trabucco, R. J. Zomer. - 2009. - URL: http://www.csi. cgiar.org

42. Афонин, А. Н. Агроэкологический атлас России и сопредельных стран: экономически значимые растения, их вредители, болезни и сорные растения / А. Н. Афонин, С. Л. Грин, Н. И. Дхюбенко, А. Н. Фролов. 2008. - URL: http://www.agroatlas.ru/ru/index.html

43. Петров, М. П. Пустыни мира / М. П. Петров. - Ленинград : Наука, 1973. - 435 с.

44. Wang, X.-H. Differences in egg thermotolerance between tropical and temperate populations of the migratory locust Locusta migratoria (Orthoptera: Acridiidae) / X.-H. Wang, L. Kang // Journal of Insect Physiology. - 2005. № 51. - P. 1277-1285.

45. Foster, J. A. Temperature dependency of wing-beat frequency in intact and deafferented locusts / J. A. Foster, R. M. Robertson // J. Exp. Biol. - 1992. - № 162. - P. 295-312.

46. Prange, H. D. Temperature regulation by respiratory evaporation in grasshoppers / H. D. Prange // J. Exp. Biol. 1990. - Vol. 154. - P. 463-474.

47. Snelling, E. Design of the insect respiratory system: a test case for symmorphosis / E. Snelling // PhD Thesis. University of Adelaide. - Australia, 2011. - $150 \mathrm{p}$.

48. Miller, G. A. Speed over efficiency: locusts select body temperatures that favour growth rate over efficient nutrient utilization / G. A. Miller, F. J. Clissold, D. Mayntz, S. J. Simpson // Proc. R. Soc. - 2009. - Ser. B. - № 276. P. 3581-3589.

49. Growth, development and daily change in body weight of Locusta migratoria manilensis (Orthoptera: Acrididae) nymphs at different temperatures / X. Tu, Z. Zhang, D. L. Johnson, G. Cao, Z. Li, S. Gao, X. Nong, G. Wang // Journal of Orthoptera Research. - 2012. - № 21 (2). - P. 133-140.

50. Jing, X.-H. Geographical variation in egg cold hardiness: a study on the adaptation strategies of the migratory locust Locusta migratoria L. / X.-H. Jing, L. Kang // Ecological Entomology. - 2003. - Vol. 28. - P. 151-158. 
51. Assessing the relationship between surface temperature and soil moisture in southern Africa / A. C. Pinheiro, C. J. Tucker, D. Entekhabi, J. L. Privette, J. A. Berry // Remote Sensing and Hydrology 2000. - Santa Fe ; New Mexico, 2000.

52. Jin, M. S. A Study of the Relations between Soil Moisture, Soil Temperatures and Surface Temperatures Using ARM Observations and Offline CLM4 Simulations / M. S. Jin, T. Mullens // Climate. - 2014. - № 2. - P. 279-295.

53. Ahmad, M. F. Prediction Of Soil Temperature By Air Temperature; A Case Study For Faisalabad / M. F. Ahmad, G. Rasul // Pakistan Journal of Meteorology. - 2008. - Vol. 5, iss. 9. - P. 19-27.

54. Islam, K. I. Correlation between Atmospheric Temperature and Soil Temperature: A Case Study for Dhaka, Bangladesh / K. I. Islam, A. Khan, T. Islam // Atmospheric and Climate Sciences. - 2015. - № 5. - P. $200-208$.

55. Zheng, D. E. A daily soil temperature model based on air temperature and precipitation for continental applications / D. E. Zheng, R. Hunt, S. W. Running // Clim. Res. - 1993. - Vol. 2. - P. 183-191.

56. Саранчовые Казахстана, Средней Азии и сопредельных территорий / А. В. Лачининский, М. Г. Сергеев, М. К. Чильдебаев, М. Е. Черняховский, Дж. А. Локвуд, В. Е. Камбулин, Ф. А. Гаппаров. - Laramie : International Association of Applied acridology and University of Wyoming, 2002. - 387 c.

57. Целлариус, Е. Ю. Температурные условия активности серого варана (Varanus griseus, Reptilia, Sauria) / Е. Ю. Целлариус, А. Ю. Целлариус // Зоологический журнал. - 1997. - Т. 76, № 2. - С. $206-211$.

58. Eltahir, A. B. E. A soil moisture-rainfall feedback mechanism / A. B. E. Eltahir // Water resources research. 1998. - № 34 (4). - P. 765-776.

59. Lloyd, J. On the temperature dependence of soil respiration / J. Lloyd, J. A. Taylor // Functional Ecology. - 1994. № 8. - P. 315-323.

60. McCumber, M. C. Simulation of the Effects of Surface Fluxes of Heat and Moisture in a Mesoscale Numerical Model. 1. Soil Layer / M. C. McCumber, R. A. Pielke // Journal of Geophysical Research. - 1981. - Vol. 86 (10). P. 9929-9938.

61. Тронин, А. А. Временные ряды спутниковых данных для прогноза вспышек саранчовых в Западной Сибири и Казахстане / А. А. Тронин // Современные проблемы дистанционного зондирования Земли из космоca. - 2007. - Вып. 4, т. 2. - С. 390-394.

62. Uvarov, B. P. The aridity factor in the ecology of Locusts and Grasshoppers of the Old World / B. P. Uvarov. Paris, 1955. $-37 \mathrm{p}$.

63. Bidau, C. J. Patterns in Orthoptera biodiversity. I. Adaptations in ecological and evolutionary contexts / C. J. Bidau // Journal of Insect Biodiversity. - 2014. - № 2 (20). - P. 1-39.

64. Sivanpillai, R. Can late summer Landsat data be used for locating Asian migratory locust, Locusta migratoria migratoria, oviposition sites in the Amudarya River delta, Uzbekistan? / R. Sivanpillai, A. V. Latchininsky // Entomologia Experimentalis et Applicata. - 2008. - № 128. - P. 346-353.

65. Sivanpillai, R. Mapping locust habitat in River Ili Delta Kazakhstan, using Landsat imagery / R. Sivanpillai, A. V. Latchininsky, K. L. Driese, V. E. Kambulin // Agriculture, Ecosystems and Environment. - 2006. Vol. 117. - P. 128-134.

66. Муратова, Н. Р. Космический мониторинг мест обитания азиатской саранчи в Казахстане / Н. Р. Муратова, Н. Ю. Цычуева, В. Е. Камбулин // Космические исследования и технологии. - 2012. - № 3. - С. 20-25.

67. Малахов, Д. В. Параметрическое дешифрирование изображений пастбищ: опыт применения данных дистанционного зондирования низкого и среднего разрешения / Д. В. Малахов, А. Ф. Исламгулова // Оптика атмосферы и океана. - 2014. - № 27 (7). - С. 587-592.

68. Предтеченский, С. А. Вредные саранчовые в СССР (обзор за 1925-1933 гг.) / С. А. Предтеченский, С. П. Жданов, А. А. Попова // Труды по защите растений. - 1935. - Сер. 1, вып. 18. - С. 1-167.

69. Прогнозирование вспышек саранчовых на основе материалов спутниковых съемок / А. А. Тронин, А. В. Горный, А. В. Киселев, С. Г. Крицук, И. Ш. Латыпов // Современные проблемы дистанционного зондирования Земли из космоса. - 2014. - Т. 11, № 4. - С. 137-150.

70. Predtechensky, S. A. The study of locust mass breeding in nesting foci and improvement of protective measures / S. A. Predtechensky // Itogi nauchno-issledovatelskih rabot Instituta zacshyty rasteniy za 1939 god. - Selkhozgiz, 1940. - P. 5-10.

71. Ramenofsky, M. Behavioral Endocrinology of Migration / M. Ramenofsky // Encyclopedia of Animal Behavior. 2010. - Vol. 1. - P. 191-199.

72. McNeill, M. R. Yersinia sp. (Mh96) - A Potential Biopesticide Of Migratory Locust Locusta Migratoria L. / M. R. McNeill, M. R. H. Hurst // New Zealand Plant Protection. - 2008. - Vol. 61. - P. 236-242.

73. Abdellaoui, K. The Antifeeding and Repellent Properties of Gibberellic Acid against Asiatic Migratory Locust Locusta migratoria migratoria / K. Abdellaoui, M. B. Halima-Kamel, M. H. Ben Hamouda // Tunisian Journal of Plant Protection. - 2009. - Vol. 4 (1). - P. 57-66.

74. Klass, J. I. Development of a model for evaluating the effects of environmental temperature and thermal behaviour on biological control of locusts and grasshoppers using pathogens / J. I. Klass, S. Blanford, M. B. Thomas // Agricultural and Forest Entomology. - 2007. - Vol. 9. - P. 189-199.

75. Fargues, J. Effects of Temperature, Humidity and Inoculation Method on Susceptibility of Schistocerca gregaria to Metarhizium favoviride / J. Fargues, A. Ouedraogo, M. S. Goettel, C. J. Lomer // Biocontrol Science and Technology. - 1997. - № 7. - P. 345-356. 


\section{References}

1. Few M., Tortorici Z. History. Duke University Press., 2013, 391 p.

2. Kambulin V. E. Materials of the International Scientific Conference "Innovative ecologically safe technologies of plant protection”. Almaty. (24-25 September 2015), pp. 36-42.

3. Sergeyev M. G., Latchininsky A. V. Entomol. Res. North Asia. 2006, pp. 284-286.

4. Gapparov F. A., Lachininsky A. V. Materials of the International Scientific Conference "Fundamental issues of entomology in the 21st century”. St. Peterburg. (16-20 May 2011), p. 30.

5. Latchininsky A. V. Materials of International Scientific Conference "Fundamental issues of entomology in the 21 st century”. St. Petersburg. 2011, p. 87.

6. Chapuis M. P., Loiseau A., Michalakis Y., Lecoq M., Franc A., Estoup A. Molecular Ecology. 2009, 18, pp. 792800 .

7. Kurishbayev A. K., Azhbenov V. K. S. Seifullin Kazakh Agrotechnical University. Bulletin of Science. 2013 , no. 1 (76), p. 42.

8. Malkovsky M. P. Proceedings of the Research Institute for Plant Protection of Kazakh Academy of Agricultural Sciences. 1961, no. 6, pp. 47-52.

9. Popova Ye. N., Popov I. O. Problems of ecological monitoring and modeling of ecosystems. Moscow: IGKE Publ., 2009, vol. 22, pp. 124-146.

10. Franklin J. Mapping species Distributions. Spatial inference and prediction. Department of Geography and the Environment, University of Texas, Austin, Texas, USA. 2012, 320 p.

11. Graham C. H., Hijmans R. J. Global Ecology and Biogeography. 2006, vol. 15, pp. 578-587.

12. Raxworthy C. J., Ingram C. M., Rabibisoa N., Pearson R. G. Syst. Biol. 2007, vol. 56, iss. 6, pp. $907-923$.

13. Pocheville A. Handbook of Evolutionary Thinking in the Sciences. 2015, pp. 547-586. Doi 10. 1007/978-94-0179014-7_26

14. Hutchinson G. E. Cold Spring Harbor Symposia on Quantitative Biology. 1957, vol. 22 (2), pp. 415-427. Doi:10. 1101/sqb. 1957. 022.01.039.

15. Rushton S. P., Ormerod S. J., Kerby G. Journal of Applied Ecology. 2004, vol. 41, pp. 193-200.

16. Aguilar M., Lado C. The ISME Journal. 2012, no. 6, pp. 1506-1514.

17. Malakhov D. V., Tsychuyeva N. Yu., Vitkovskaya I. S. Modern problems of remote sensing of the Earth from space. 2017, vol. 14 (1), pp. 113-124. Doi: 10. 21046/2070-7401-2017-14-1-113-124.

18. Babar Sh., Amarnath G., Reddy C. S., Jentsch Anke, Sudhakar S. Current Science. 2012, vol. 102, no. 8 (25), pp. 1157-1165.

19. Ayala D., Costantini C., Ose K., Kamdem G. C., C. Antonio-Nkondjio, Agbor J. -P., Awono-Ambene P., Fontenille D., Simard F. Malaria Journal. 2009, no. 8, p. 307.

20. Beaumont L. J., Hughes L., Poulsen M. Ecological Modelling. 2005, no. 186, pp. 250-269.

21. Sanchez I., Liria J., Feliciangeli M. D. International Journal of Zoology. 2009, vol. 2015. Article ID 108306. 9 p. DOI: http://dx. doi. org/10. 1155/2015/108306

22. Groff L. A., Marks S. B., Hayes M. P. Herpetological Conservation and Biology. 2013, no. 9 (2), pp. 354-368.

23. Litvinchuk S. N., Schepina N. A., Munkhbaatar M., Munkhbayar Kh., Borkin L. J., Kazakov V. I., Skorinov D. V. Russian Journal of Herpetology. 2014, vol. 21, no. 4, pp. 303-314.

24. Malakhov D. V., Dujsebayeva T. N. Proceedings of the International Symposium on Biological Resources Protection and Management in the Arid Central Asia. Urumqi. Xinjiang. 2014, pp. 6-7.

25. Skorinov D. V., Doronin I. V., Kidov A. A., Tuniyev B. S., Litvinchuk S. N. Russian Journal of Herpetology. 2014, vol. 21, no. 4, pp. 251-268.

26. Barnagaud J-Y., Devictor V., Jiguet F., Barbet-Massin M., I. Le Viol PLoS ONE. 2012, no. 7 (3). e32819. DOI: 10.1371/journal. pone. 0032819

27. Parra J. L., Graham C. C., Freile J. F. Ecography. 2004, vol. 27, pp. 350-360.

28. Peterson A. T., Robins C. R. Conservation Biology. 2003, vol. 17, no. 4, pp. 1161-1165.

29. Kayijamahe E. Spatial modelling of mountain gorilla (Gorilla beringei beringei) habitat suitability and human impact. PhD Thesis, International Institute for Geo-Information Science and Earth Observation, Enschede, Netherlands. 2008, $50 \mathrm{p}$.

30. Rood E., Ganie A. A., Nijman V. Diversity and Distributions. 2010, no. 16, pp. 975-984.

31. Lozier J. D., Aniello P., Hickerson M. J. Journal of Biogeography. 2009, vol. 36, iss. 9, pp. 1623-1627. Doi: 10. 1111/j. 1365-2699. 2009. 02152. x

32. Duysebayeva T. N., Malakhov D. V., Cherednichenko A. V. 1st International Scientific and Practical Conference "Desertification of Central Asia: Assessment, Forecast, Management”. Astana, 2014, pp. 206-211.

33. Waltari E., Hijmans R. J., Peterson A. T., Nyari A. S., Perkins S. L., Guralnick R. P. PLoS ONE. 2007, no. 2 (7). e563. doi:10. 1371/journal. pone. 0000563

34. Plisak R. P. Izmeneniye rastitelnosti delty reki Ili pri zaregulirovanii stoka [Changes in the vegetation of the Ili River delta with regulating runoff]. Alma-Ata: Nauka Publ. 1981, 215 p.

35. Dujsebayeva T. N., Malakhov D. V. Russian Journal of Herpetology. 2017, vol. 24, no. 3, pp. $171-192$.

36. O’Donnell M. S., Ignizio D. A. U. S. Geological Survey Data Series. 2012, vol. 691, 10 p. 
37. Hijmans R. J., Cameron S. E., Parra J. L., Jones P. G., Jarvis A. International Journal of Climatology. 2005, vol. 25, pp. 1965-1978.

38. Booth T. H., Nix H. A., Busby J. R., Hutchinson Michael F. Diversity and Distributions. 2014, vol. 20, pp. 1-9.

39. Kriticos D. J., Webber B. L., Leriche A., Ota N., Macadam I., Bathols J., Scott J. K. Methods in Ecology and Evolution. 2012, vol. 3, pp. 53-64. DOI: 10. 1111/j. 2041-210X. 2011. 00134. x

40. New M., Lister D., Hulme M., Makin I. ClimRes. 2002, vol. 21, pp. 1-25.

41. Trabucco A., Zomer R. J. Global Potential Evapo-Transpiration (Global-PET) and Global Aridity Index (GlobalAridity) Geo-Database. CGIAR Consortium for Spatial Information. 2009. Available online from the CGIAR-CSI GeoPortal at: http://www. csi. cgiar. org

42. Afonin A. N., Grin S. L., Dkhyubenko N. I., Frolov A. N. Agroekologichesky atlas Rossii i sopredelnykh stran: ekonomicheski znachimye rasteniya, ikh vrediteli, bolezni i sornye rasteniya [Agroecological atlas of Russia and neighboring countries: economically significant plants, their pests, diseases and weeds]. 2008. Available at: http://www. agroatlas. ru/ru/index. html.

43. Petrov M. P. Pustyni mira [Deserts of the world]. Leningrad: Nauka Publ, 1973, 435 p.

44. Wang X. -H., Kang L. Journal of Insect Physiology. 2005, no. 51, pp. 1277-1285.

45. Foster J. A., Robertson R. M. J. Exp. Biol. 1992, no. 162, pp. 295-312.

46. Prange H. D. J. exp. Biol. 1990, vol. 154, pp. 463-474.

47. Snelling E. Design of the insect respiratory system: a test case for symmorphosis. PhD Thesis. University of Adelaide. Australia. 2011, 150 p.

48. Miller G. A., Clissold F. J., Mayntz D., Simpson S. J. Proc. R. Soc. 2009, ser. B, no. 276, pp. 3581-3589.

49. Tu X., Zhang Z., Johnson D. L., Cao G., Li Z., Gao S., Nong X., Wang G. Journal of Orthoptera Research. 2012 , no. 21 (2), pp. 133-140.

50. Jing X. -H., Kang L. Ecological Entomology. 2003, vol. 28, pp. 151-158.

51. Pinheiro A. C., Tucker C. J., Entekhabi D., Privette J. L., Berry J. A. Remote Sensing and Hydrology 2000 (Proceedings of a symposium held at Santa Fe). New Mexico, USA, April 2000.

52. Jin M. S., Mullens T. Climate. 2014, no. 2, pp. 279-295.

53. Ahmad M. F., Rasul G. Pakistan Journal of Meteorology. 2008, vol. 5, iss. 9, pp. 19-27.

54. Islam K. I., Khan A., Islam T. Atmospheric and Climate Sciences. 2015, no. 5, pp. 200-208.

55. Zheng D. E., Hunt R., Running S. W. Clim. Res. 1993, vol. 2, pp. 183-191.

56. Lachininsky A. V., Sergeyev M. G., Childebayev M. K., Chernyakhovsky M. E., Lokvud Dzh. A., Kambulin V. E., Gapparov F. A. Saranchovye Kazakhstana, Sredeny Azii i sopredelnykh territory [Locusts in Kazakhstan, Middle Asia and adjacent territories]. Laramie: International Association of Applied acridology and University of Wyoming. 2002, $387 \mathrm{p}$

57. Tsellarius Ye. Yu., Tsellarius A. Yu. Zoologichesky zhurnal [ ]. 1997, vol. 76, no. 2, pp. 206-211.

58. Eltahir A. B. E. Water resources research. 1998, no. 34 (4), pp. 765-776.

59. Lloyd J., Taylor J. A. Functional Ecology. 1994, no. 8, pp. 315-323.

60. McCumber M. C., Pielke R. A. Journal of Geophysical Research. 1981, vol. 86 (10), pp. 9929-9938.

61. Tronin A. A. Modern problems of remote sensing of the Earth from space. Moscow, 2007, iss. 4, vol. 2, pp. 390394.

62. Uvarov B. P. The aridity factor in the ecology of Locusts and Grasshoppers of the Old World. Paris. $1955,37 \mathrm{p}$.

63. Bidau C. J. Journal of Insect Biodiversity. 2014, no. 2 (20), pp. 1-39.

64. Sivanpillai R., Latchininsky A. V. Entomologia Experimentalis et Applicata. 2008, no. 128, pp. $346-353$.

65. Sivanpillai R., Latchininsky A. V., Driese K. L., Kambulin V. E. Agriculture, Ecosystems and Environment. 2006, vol. 117, pp. 128-134.

66. Muratova N. R., Tsychuyeva N. Yu., Kambulin V. E. Space researches and technologies. 2012, no. 3, pp. $20-25$.

67. Malakhov D. V., Islamgulova A. F. Atmosphere and Ocean Optics. 2014, no. 27 (7), pp. 587-592.

68. Predtechensky S. A., Zhdanov S. P., Popova A. A. Proceedings on plant protection. 1935, ser. 1, vol. 18, pp. 1167.

69. Tronin A. A., Gorny A. V., Kiselev A. V., Kritsuk S. G., Latypov I. Sh. Modern problems of remote sensing of the Earth from space. 2014, vol. 11, no. 4, pp. 137-150.

70. Predtechensky S. A. Results of the research works of the Institute for Plant Protection in 1939. Selkhozgiz. 1940, pp. 5-10.

71. Ramenofsky M. Encyclopedia of Animal Behavior. 2010, vol. 1, pp. 191-199.

72. McNeill M. R., Hurst M. R. H. New Zealand Plant Protection. 2008, vol. 61, pp. 236-242.

73. Abdellaoui K., Halima-Kamel M. B., Ben Hamouda M. H. Tunisian Journal of Plant Protection. 2009, vol. 4 (1). pp. 57-66.

74. Klass J. I., Blanford S., Thomas M. B. Agricultural and Forest Entomology. 2007, vol. 9, pp. 189-199.

75. Fargues J., Ouedraogo A., Goettel M. S., Lomer C. J. Biocontrol Science and Technology. 1997, no. 7, pp. 345356. 